\title{
УТИЛІЗАЦЯ ФОТОЕЛЕКТРИЧНИХ МОДУЛІВ. ПРОБЛЕМИ ТА МІЖНАРОДНИЙ ДОСВІД
}

\author{
В.О. Пундєв, В.Ф. Рєзцов, чл.-кор. НАН України, докт. техн. наук, Т.В. Суржик, канд. техн. наук, В.І. Шевчук, \\ I.O. Шейко
}

Інститут відновлюваної енергетики НАН України, 02094, вул. Гната Хоткевича, 20А, м. Київ, Україна.

\begin{abstract}
В статті піднято важливе і актуальне вже на зараз питання стосовно фотоелектричних станиій (ФЕС), які не впливають на навколишнє середовище за умови експлуатаиії, але можуть негативно впливати на екологію в Україні, за умови виведення їх з експлуатації по закінченню гарантованого ефективного терміну роботи, а саме накопичення шкідливих речовин і сполук, які входять до складу фотоелектричних модулів (ФЕМ).

В роботі описано основні види фотоелектричних модулів, які на даний час масово випускаються виробниками $i$ використовуються в фотоелектричних станціях в світі та їх основні складові частини. Визначено проблеми, які виникають за умови виходу ФЕМ з ладу внаслідок закінчення терміну експлуатації чи пошкодження тощзо.

Подано огляд стану справ стосовно утилізачії основних складових частин фотоелектричних станиій - фотоелектричних модулів в передових країнах світу в розрізі нормативного забезпечення иих робіт та розробки необхіднх додаткових нормативних актів, а також в розрізі вже існуючих технологій, які при цьому застосовуються, або розроблені чи розробляються. Описано необхідність та можсливості повторного використання переважної більшості з отриманих при утилізації фотоелектричних модулів матеріалів і сполук.

Огляд, його аналіз та тендениії стрімкого розвитку фотоенергетики в світі націлюють на необхідність до створення вже зараз, не чекаючи масового виходу з ладу ФЕМ, иілого сектору промисловості, щңо займатиметься утилізацією відпрацьованих фотоелектричних модулів та підготовкою продуктів утилізачії до повторного використання, щэо значно зменшить негативне навантаження на довкілля.

Намічено цілі та задачі, які необхідно почати виконувати вже зараз $і$ виконати в якомога короткий термін в Украйні у напрямку утилізації фотоелектричних модулів. Це наступні кроки: розроблення та впровадження необхідних нормативних актів, нових ефективних технологій переробки ФЕМ та спеціалізованих виробництв (або модернізація та підлатування вже існуючих на базі підприємств з виготовлення ФЕМ) тощо. Бібл. 12, рис. 2.
\end{abstract}

Ключові слова: екологія, нормативне забезпечення, сонячний модуль, фотоелектрична станція, утилізація.

\section{DISPOSAL OF PHOTOVOLTAIC MODULES. PROBLEMS AND INTERNATIONAL EXPERIENCE}

V. Pundiev, V. Ryeztsov, corresponding member of the NAS of Ukraine, doctor of technical science, T. Surzhyk, candidate of technical science, V. Shevchuk, I. Sheiko

Institute of Renewable Energy of the National Academy of Sciences of Ukraine, 02094, 20A Hnata Khotkevycha St., Kyiv, Ukraine.

The article raises an important and topical issue of PV plants, which do not affect the environment in operation, but can negatively affect the environment in Ukraine, provided they are decommissioned at the end of the guaranteed effective life, and the accumulation of harmful substances and compounds that are part of PV modules (PVM).

The paper describes the main types of $P V$ modules, which are currently mass-produced by manufacturers and used in $P V$ plants in the world and their main components. Problems that arise in the event of failure of the PVM due to expiration or damage, etc. are identified. The state of affairs concerning utilization of the main components of PV plants - PVM in the advanced countries of the world in the plane of normative maintenance of these works, development of necessary additional regulations, and also already existing technologies which are applied or developed is considered. The necessity and possibilities of reuse of the vast majority of PVM of materials and compounds obtained during utilization are described. The review, its analysis and the trends of rapid development of photovoltaics in the world necessitate the creation of an entire industry sector in Ukraine, which will dispose of used PVM and prepare recycling products for reuse now, without waiting for mass failure of PVM. This will significantly reduce the negative burden on the environment.

The goals and tasks to be fulfilled by Ukraine in the shortest possible time in the direction of utilization of PVM are outlined. These are the following steps: development and implementation of the necessary regulations, new effective technologies for processing $P V M$ and specialized industries (or modernization and adjustment of existing on the basis of enterprises for the manufacture of PVM), etc. Ref. 12, fig. 2.

Keywords: ecology, regulatory support, reuse, solar module, photovoltaic plants, utilization.

(C) В.О. Пундєв, В.Ф. Рєзцов, Т.В. Суржик, В.І. Шевчук, І.О. Шейко, 2020 

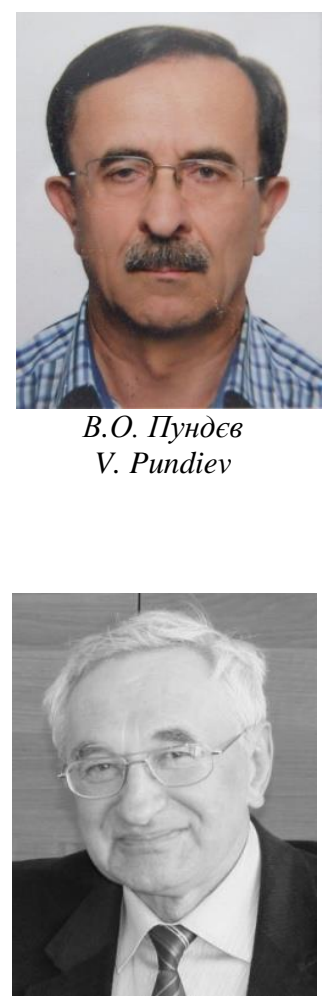

B.Ф. Рєзйов

V. Rieztsov

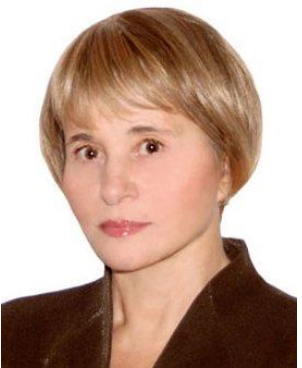

T.В. Суржик

T. Surzhyk

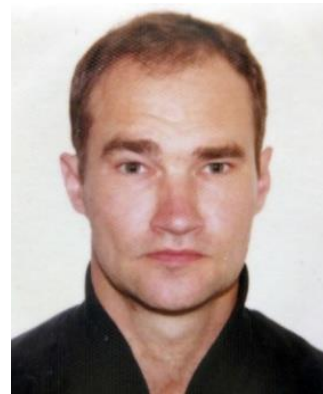

B.I. Шевчук

V. Shevchuk
Відомості про автора: науковий співробітник відділу сонячної енергетики в Інституті відновлюваної енергетики НАН України.

Освіта: Ворошиловградський машинобудівельний інститут, факультет електромашинобудування, спеціальність - електричні машини та апарати.

Наукова сфера: відновлювана енергетика, зокрема - сонячна енергетика.

Публікації: 25

ORCID: 0000-0003-3750-8812

Контакти: +38 (044) 206-28-09

e-mail: renewable@ukr.net

Відомості про автора: чл.-кор. НАН України, докт. техн. наук, професор, заступник директора 3 наукових питань, завідувач відділу сонячної енергетики в Інституті відновлюваної енергетики НАН України. Освіта: Харківський авіаційний інститут, факультет двигунів літальних апаратів, спеціальність - інженер-механік.

Наукова сфера: відновлювана енергетика.

Публікації: 306, 5 монографій, 20 патентів.

ORCID: 0000-0003-2926-1733

Контакти: +38 (044) 206-28-09

e-mail: renewable@ukr.net

Відомості про автора: кандидат технічних наук, вчений секретар Інституту відновлюваної енергетики НАН України.

Освіта: Київський інженернобудівельний інститут, спеціальність теплогазопостачання та вентиляція.

Наукова сфера: відновлювана енергетика.

Публікації: 186, 2 монографії, 26 патентів.

ORCID: 0000-0002-1418-7748

Контакти: +38 (044) 206-28-09

e-mail: renewable@ukr.net

Відомості про автора: науковий співробітник відділу сонячної енергетики в Інституті відновлюваної енергетики НАН України.

Освіта: Київський політехнічний інститут, електротехнічний факультет, спеціальність - електричні станції.

Наукова сфера: відновлювана енергетика, зокрема - сонячна фотоенергетика.

Публікації: 40.

ORCID: 0000-0002-4176-7799

Контакти: +38 (044) 206-28-09

e-mail: renewable@ukr.net
Author information: research associate of Solar Power Engineering Department of Institute of Renewable Energy at NAS of Ukraine.

Education: The Voroshilovgrad Machine-

Building Institute in Electrical Machines and Devices.

Research area: renewable power in particular solar power

Publications: 25 .

ORCID: 0000-0003-3750-8812

Contacts: +38 (044) 206-28-09

e-mail: renewable@ukr.net

Author information: corresponding member of NAS of Ukraine, doctor of technical sciences, professor, deputy director of research, head of Solar Energy Department, Institute of Renewable Energy of the National Academy the Sciences of Ukraine.

Education: Kharkiv Aviation Institute, Faculty of Aircraft Engine Engines, speciality mechanical engineer.

Research area: renewable energy.

Publications: 306, 5 monographs, 20 patents.

ORCID: 0000-0003-2926-1733

Contacts: +38 (044) 206-28-09

e-mail: renewable@ukr.net

Author information: candidate of science, science secretary in the Institute of Renewable Energy of the National Academy the Sciences of Ukraine.

Education: Kyiv Engineering Building -

Institute, specialty - gas-heating and ventilation Research area: renewable energy.

Publications: 186, 2 monographs, 26 patents.

ORCID: 0000-0002-1418-7748

Contacts: +38 (044) 206-28-09

e-mail: renewable@ukr.net

Author information: research associate of Solar Power Engineering Department of Institute of Renewable Energy at NAS of Ukraine.

Education: The Kyiv Polytechnic Institute in Power Plants.

Research area: renewable power, in particular photovoltaics

Publications: 40 .

ORCID: 0000-0002-4176-7799

Contacts: +38 (044) 206-28-09

e-mail: renewable@ukr.net 


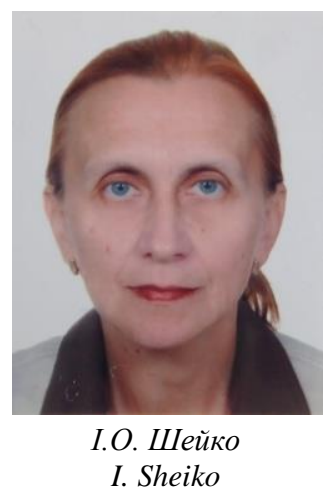

Відомості про автора: провідний інженер відділу сонячної енергетики в Інституті відновлюваної енергетики НАН України.

Освіта: Київський політехнічний інститут, факультет автоматики та приладобудування, спеціальність електронні обчислювальні машини

Наукова сфера: відновлювана енергетика, зокрема - сонячна енергетика.

Публікації: 5.

ORCID: 0000-0002-5770-3677

Контакти: +38 (044) 206-28-09

e-mail: renewable@ukr.net
Author information: leading associate of Solar Power Engineering Department of Institute of Renewable Energy at NAS of Ukraine.

Education: Kiev Polytechnic Institute, Faculty of Automation and Electrical Equipment, specialty - electronic machined. Faculty of Automation and Instrumentation, specialty electronic computers.

Research area: renewable power in particular solar power.

Publications: 5 .

ORCID: 0000-0002-5770-3677

Contacts: +38 (044) 206-28-09

e-mail: renewable@ukr.net
Вступ. Тенденції розвитку сонячної фотоенергетики свідчать, що введення потужностей фотоелектричних станцій (ФЕС) як у всьому світі, так і в Україні, в останній час стрімко зростає. Станом на 1-й квартал 2020 року встановлена потужність об'єктів сонячної фотоенергетики в Україні становить вже 4925 МВт. Тільки у 2019 році їх було введено в дію загальною встановленою потужністю 3537 МВт. На кінець 2019 року частка виробленої сонячними електростанціями електричної енергії в загальній генерації України склала 1,65\%, або 52\% від усіх джерел відновлювальної енергетики [3]. Це дуже стрімке зростання впровадження сонячної фотоенергетики в Україні, яке, скоріше за все, збереже такі темпи i в найближчому майбутньому. У 2018 р. Україна набула статусу повноправного члена Міжнародного агентства 3 відновлюваних джерел енергії (IRENA), що $є$ великим досягненням і що зобов'язує до ще більших досягнень в області розвитку та впровадження відновлюваних джерел енергії.

Сонячна фотоенергетика - надзвичайно актуальний і перспективний, а також екологічно чистий спосіб отримання електроенергії. Генеруюча складова ФЕС фотоелектричні модулі (ФЕМ) є довговічними, ефективними і безпечними в процесі експлуатації. Однак поряд 3 безсумнівними екологічними перевагами використання ФЕС для перетворення сонячної енергії в електричну існує проблема утилізації фотоелектричних модулів, які відпрацювали свій термін і зняті з експлуатації, або вийшли $з$ ладу з інших причин. Вже зараз під час монтування та роботи ФЕС відбувається заміна пошкоджених або тих, що вийшли з ладу, фотоелектричних модулів. Кількість таких ФЕМ зростає 3 кожним роком, що при неправильній або неконтрольованій їх переробці в найближчому майбутньому може стати величезною проблемою для навколишнього середовища. В Україні на даний час підприємства по переробці фотоелектричних модулів відсутні, як відсутні і вимоги щодо їх утилізації.

Постановка завдання. Моніторинг викладеної у вільному доступі інформації щодо стану справ стосовно виведення 3 експлуатації ФЕС та утилізації відпрацьованих та тих, що вийшли з ладу, складових частин ФЕС в Свропі та світі в цілому показує, що до цього важливого в енергетичному, екологічному та соціальному плані процесу треба готуватися планово та заздалегідь. В найбільшій мірі це стосується утилізації фотоелектричних модулів та можливості повторного використання продуктів їх переробки.

Справа в тому, що передові та промислово розвинені країни світу, які значно раніше від України почали диверсифікацію своїх енергетичних галузей шляхом широкого впровадження відновлюваних джерел енергії i зокрема фотоелектричної енергетики, вже стикнулися 3 проблемами виведення 3 експлуатації ФЕС та утилізації відпрацьованих та тих, що вийшли з ладу їх складових частин. Вони досить успішно створили та продовжують створювати необхідну інфраструктуру та технології в цьому напрямку 3 неухильним дотриманням розроблених нормативних баз.

Автори в цій роботі поставили перед собою завдання виконати аналіз вже досягнутого провідними країнами світу досвіду та напрацювань, окреслити основні напрямки та задачі, які необхідно вже зараз розробляти, готувати та починати виконувати в Україні стосовно підготовки нормативної бази та необхідної інфраструктури щодо виведення 3 експлуатації ФЕС та утилізації відпрацьованих та тих, що вийшли 3 ладу, основних складових частин ФЕС - фотоелектричних модулів.

Виклад основного матеріалу. Проблеми, 3 якими доводиться стикатися за умови утилізації 
фотоелектричних модулів, вже було стисло розглянуто при розробленні ефективних заходів і рекомендацій зі зменшення впливу на довкілля при впровадженні технологій фотоенергетики в Україні $[1,2]$. В даній статті це питання розглядається більш детально 3 аналізом світового досвіду та вже існуючої міжнародної нормативної бази.

3 точки зору екологічного аспекту переробка відпрацьованих сонячних модулів однозначно $є$ необхідною, оскільки ФЕМ, що виробляються та експлуатуються сьогодні, містять токсичні речовини, які $є$ шкідливими для навколишнього середовища.

Сучасні фотоелектричні модулі мають термін експлуатації 30-50 років (термін експлуатації перших модулів становить 25-30 років), а через 30 років експлуатації їх ефективність починає знижуватися i вони потребуватимуть заміни та утилізації.

Основу ФЕМ складають фотоелементи, для більшості 3 яких основним матеріалом у виробництві $\epsilon$ дешевий $\mathrm{i}$ поширений кремній (близько 80 \%). Найбільш безпечними 3 ряду кремнієвих фотоелементів вважаються модулі 3 аморфного кремнію.

Окремим рядом фотоелектричних модулів, що випускає світова промисловість, $є$ ФЕМ на базі плівкових технологій CIS (селеніда міді та індія) i CdTe/CdS (кадмій/телур, кадмій/сірка), а також на базі арсенід-галієвих (GaAs) сонячних елементів. Ці модулі є особливо привабливими для фотоенергетики завдяки високому ККД (ï теоретичний ККД доходить до 30 \%, а практичний вже знаходиться в межах 22-25\%). Але такі ФЕМ містять отруйні речовини (свинець, кадмій, галій, миш'як тощо) i ïx переробка потребує використання спеціальних технологій з очисткою, нейтралізацією отруйних та шкідливих речовин тощо.

Стратегія та стан справ щзодо утилізації $\Phi E M$ в світі. У сфері регулювання утилізації відходів відпрацьовані фотоелектричні модулі відносять до електронних відходів. Дана категорія має маркування «е-waste». Міжнародне агентство відновлюваної енергетики (IRENA) і Міжнародне енергетичне агентство (MEA) опублікували в 2016 році спільну доповідь, яка повинна стати алгоритмом 3 максимально грамотної утилізації фотоелектричних модулів. Прогнозується, що до 2030 року світові відходи фотоенергетики (накопиченим підсумком) складуть 1,7-8 млн. тон в залежності від того, чи будуть це regular loss (модулі, що відпрацювали 25-30-річний строк служби), або ж early loss (передчасно вилучені (до закінчення їх строку служби) за різних причин модулі (заміна застарілого обладнання, механічне пошкодження тощо). За прогнозами вже до 2050 року обсяги електронних відходів в сонячній енергетиці складуть близько 70-80 мільйонів тон (рис. 1, 2) [4].

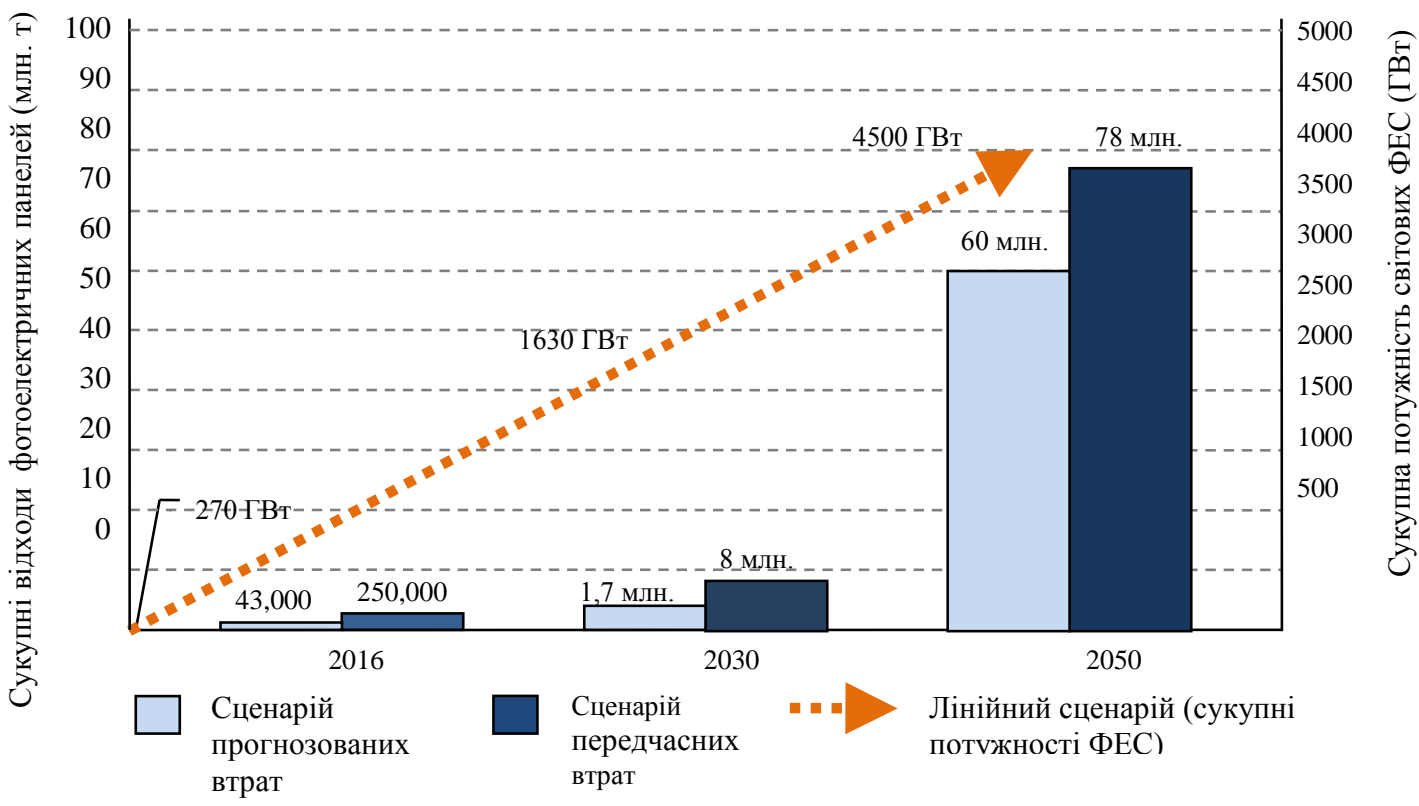

Рис. 1. Глобальний огляд прогнозів відходів фотоелектричних панелей, 2016-2050 рр.

Fig. 1. Overviev of global PV panel waste projections, 2016-2050. 


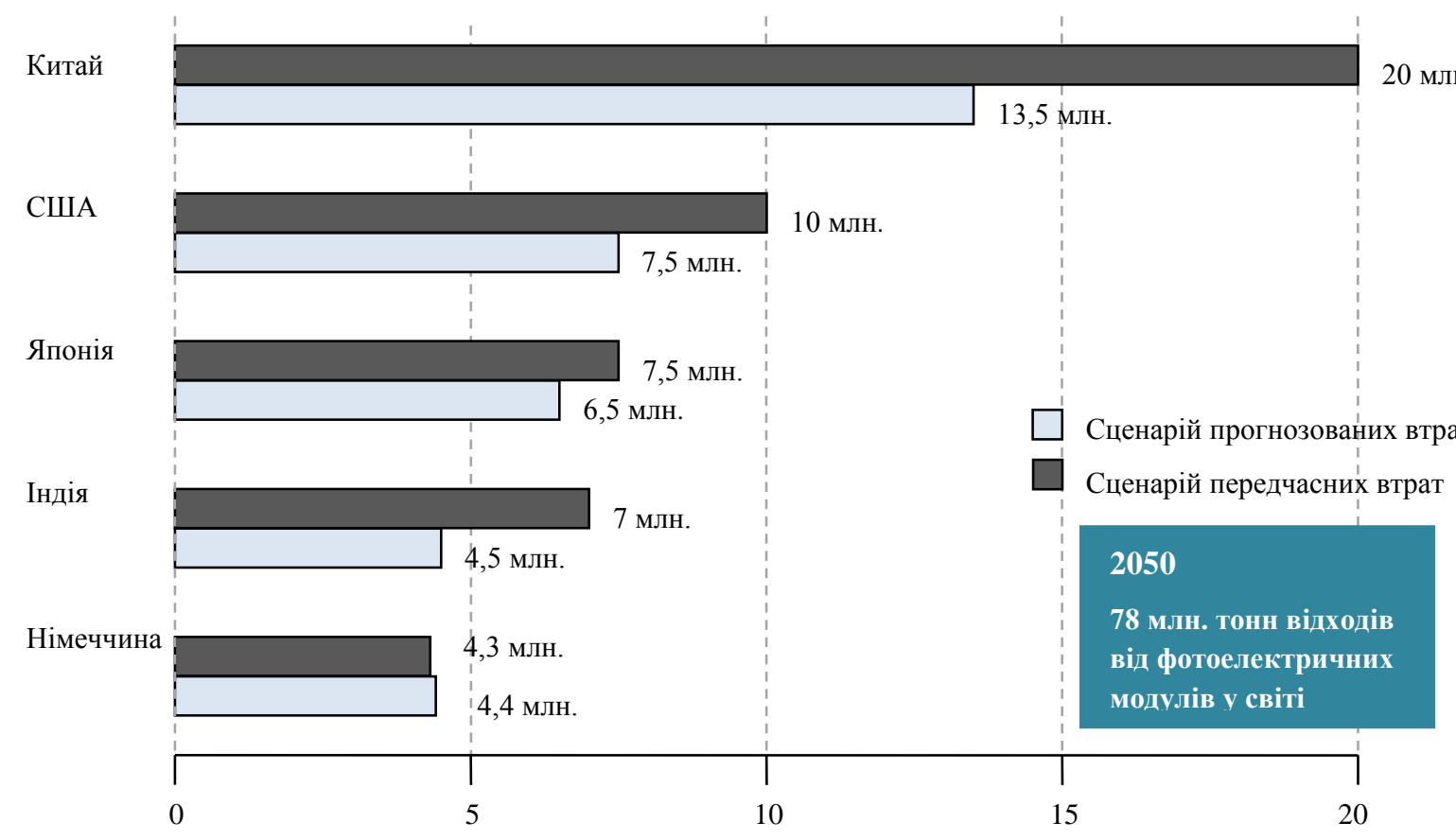

Рис. 2. Накопичувальні відходи фотоелектричних модулів (млн. тон) в розрізі країн-лідерів до 2050 р.

Fig. 2. Cumulative waste volumes of top five countries for of end-of-life PV panels in 2050 (million t).

Фахівці підрахували - якщо кількість відходів сонячних модулів із відпрацьованим строком служби до 2030-го року конвертувати у грошовий еквівалент шляхом вторинної переробки і вилучення матеріалів, то сума складе близько 450 мільйонів доларів США. 3 такої кількості відходів можна зробити 60 мільйонів нових сонячних модулів, що дорівнюе за потужністю 18 ГВт. До 2050 року ця цифра збільшиться до 15 мільярдів доларів за рік і з такої кількості відходів можна буде зробити 2 млрд. сонячних модулів, що еквівалентно 630 ГВт [4].

В більшості країн фотоелектричні модулі класифікуються як загальні, або промислові відходи, і управління ними здійснюється відповідно до звичайних вимог щодо обробки та утилізації відходів. Крім такого універсального регулювання розробляються добровільні нормативні підходи для спеціального поводження із такого роду відходами.

Європейський союз (СС) першим ввів правила утилізації відходів сонячних електростанцій, які регулюються Директивою 2012/19/EU про відходи електричного та електронного обладнання WEEE (Waste Electrical and Electronic Equipment). У 2012 році положення Директиви WEEE були включені в національні законодавства країн-членів $Є C$, на ринку якого переробка сонячних модулів $є$ обов'язковою. Крім того Європейський комітет зі стандартизації електротехніки (CENELEC) розробив додаткові стандарти для збору і переробки фотоелектричних панелей (EN50625-2-4 та TS50625-3-5) [5, 6]. У стандартах викладені різні адміністративні, організаційні та технічні вимоги, спрямовані на запобігання забруднення i неналежного поводження, мінімізацію викидів, сприяння збільшенню частки відновлених матеріалів i операцій із глибокої переробки. Вони також перешкоджають можливості відвантаження відпрацьованих модулів на об'єкти, які не відповідають стандартним вимогам охорони навколишнього середовища і здоров'я.

В країнах $\mathrm{CC}$ підприємства по переробці фотоелектричних модулів використовують технології утилізації сонячних елементів (від повторного використання окремих компонентів до розплавлення компонентів модуля) в залежності від типу елементів і технологічних особливостей. Європарламент в країнах Євросоюзу здійснив практично обов'язковим повернення фотоелектричних модулів на переробку в якості електронних відходів. Ключовим фактором успіху нових правил СС повинно стати створення широкої функціональної інфраструктури зі збору та переробки фотоелектричних модулів.

У Сполучених Штатах утилізація фотопанелей регулюється Законом про збереження та відновлення ресурсів (Resource 
Conservation and Recovery Act), який є правовою основою для управління небезпечними та безпечними відходами. У 2016 році Асоціація сонячної енергетики США (SEIA) у партнерстві iз виробниками сонячних модулів та монтажними організаціями запустила національну програму добровільної утилізації фотопанелей, яка спрямована на те, щоб зробити ефективні рішення по переробці більш доступними для споживачів. У 2019 році у США було опубліковано новий стандарт управління сталим розвитком для фотоелектричних модулів - NSF/ANSI 457, метою якого $є$ встановлення критеріїв ефективності для фотоелектричних модулів та показників стійкого їх лідерства на ринку [7]. Цей стандарт включає також критерії управління цими виробами після закінчення терміну їх експлуатації.

У Японії відпрацьовані сонячні панелі підпадають під загальні регламенти з управління відходами (Waste Management and Public Cleansing Act). У 2015 році була розроблена дорожня карта для просування схеми збору, переробки та належного поводження із відпрацьованим обладнанням відновлюваної енергетики. У 2017 році японська Асоціація сонячної енергетики (Japan Photovoltaic Energy Association - JPEA) опублікувала керівництво щодо належного поводження із сонячними модулями після закінчення терміну їх служби (документ має рекомендаційний характер). Додатково, Національний інститут передових промислових наук і технологій (NEDO) розробляє технологію переробки. На сьогодні Уряд Японії планує оприлюднити нові заходи, які мають на меті переконати, що утилізовані сонячні панелі не завдають шкоди навколишньому середовищу. Міністерство промисловості хоче зобов'язати операторів ринку сонячних панелей виділяти кошти для покриття витрат на утилізацію i, щоб запобігти зловживанням, надавати ці кошти третій стороні [8].

Із загальнодоступних джерел відомо, що у Китаї поки що немає спеціальних правил по утилізації сонячних модулів, але це не заважає займатися їх переробкою. У рамках Національної науково-технічної програми протягом 12-ї п’ятирічки в країні фінансувалися дослідження і розробки у галузі поводження із «сонячними відходами».

В Індії відходи фотоелектричної енергетики знаходяться у веденні Міністерства навколишнього середовища, лісів та зміни клімату відповідно до Правил поводження із твердими відходами 2016 року і Правилами поводження із небезпечними і іншими відходами (управління і транскордонне переміщення).
Технології переробки фотомодулів. 3 огляду на викладене вище, більшість країн-лідерів, зокрема Китай, США, Японія, країни СС, активно інвестують в дослідження і розробки технологій по переробці сонячних панелей. У всьому світі виробники електроніки, до якої відносять i сонячні модулі, вже несуть відповідальність за повний цикл життя своєї продукції, в тому числі й за її переробку.

Утилізація сонячних модулів відбувається за допомогою лазерної, термічної і механічної переробки. Механічний метод домінував на ринку досить тривалий час (з 2013 по 2017 роки), забезпечуючи переробку близько 55\% електронного сміття. Це можна пояснити екологічністю і економічністю такого процесу. Але, як передбачається, до 2023 року в лідерах як за обсягами, так і у вартісному вираженні, буде домінувати метод лазерної переробки.

До складу ФЕМ крім кремнію входять такі матеріали і сполуки, як ламінат, пластик, скло, мідь, алюміній, свинець, олово, срібло тощо, які за умови утилізації можуть бути вивільнені (відокремлені) i направлені на повторне використання. Наприклад, в процентному співвідношенні панель 3 кристалічного кремнію це $76 \%$ скла, 10\% полімерних матеріалів, 8\% алюмінію, 5\% кремнієвих напівпровідників, 1\% міді, менш $0,1 \%$ срібла, олова і свинцю. Скло складає основу тонкоплівкових каркасних модулів - 89\% (CIGS) і 97\% (CdTe) [9], яке може бути також повторно використане після переробки.

Процес переробки фотоелектричних модулів можна розділити на два етапи:

- груба переробка (виймання компонентів 3 міді, алюмінію, скла);

- тонка переробка (витяжка хімічних складових модуля).

Груба переробка ФЕМ, за своєю суттю, є технологією вторинного застосування скла 3 ламінованим покриттям i не забезпечуе відновлення екологічно небезпечних матеріалів (свинець $(\mathrm{Pb})$, кадмій $(\mathrm{Cd})$, селен $(\mathrm{Se})$ тощо), або цінних матеріалів (срібло (Ag), індій (In), телур $(\mathrm{Te})$, силіцій $(\mathrm{Si})$ тощо).

Тонка переробка ФЕМ включає три етапи:

1) підготовчий етап, який полягає $\mathrm{y}$ вилученні розподільної коробки і рами пристрою;

2) усунення ламінуючого покриття (плівки) або деламінація;

3) зняття металів і скляних складових.

В європейських країнах зараз для повторного використання витягується вже близько 70 \% компонентів сонячних модулів, які 
утилізуються. Крім того, міжнародні Директиви регламентують дотримання вимог вмісту небезпечних елементів у вторинній сировині (кадмій і селен - не більше 1 мг на кілограм для кремнісвих панелей і не більше 10 мг - для не кремнієвих, свинець - не більше 100 мг у сухій речовині).

Сьогодні багато виробників в Свропі і світі вже пропонують послуги з утилізації випущених ними сонячних модулів i створюють спеціалізовані підприємства по їх переробленні. Тут діє принцип «розширеної відповідальності виробника» (extended-producer-responsibility), яка виходить за рамки стадій продажу та експлуатації, і охоплює також стадію поводження з продуктом після завершення його терміну служби. Така політика виробників обумовлена не тільки постійним посиленням вимог регуляторів або «підвищеною соціальною відповідальністю», а ще й тому, що переробка ФЕМ не позбавлена економічного сенсу - багато 3 хімічних речовин мають великий потенціал для переробки через їх цінність. Тобто, така галузь, як переробка фотоелектричних модулів, матиме важливе значення у переході світу до сталого, економічно вигідного майбутнього енергетичного ринку на основі відновлюваних джерел енергії [4].

У 2018 році французька компанія Veolia відкрила завод по вторинній переробці сонячних модулів. Раніше у Франції, використані або зламані сонячні панелі просто перероблялися установками для вторинної переробки скла загального призначення. При такому процесі вдавалося витягти скло і алюмінієві рами, все інше спалювалося. Зараз же на новому заводі Veolia роботи розбирають $\mathrm{PV}$-панелі для вилучення скла, кремнію, пластмаси, міді і срібла. Потім ці елементи подрібнюють в гранули і подають як готову сировину для виробництва нових сонячних панелей.

У Сполучених Штатах в 2000-х роках розробили технологію переробки тонкоплівкових СdTе-модулів. Вперше ii застосувала фотогальванічна компанія First Solar. Завдяки розробленій технології повторно можна використовувати $\quad 95 \%$ напівпровідникових матеріалів і 90\% скла [10]. Всі демонтовані елементи сонячних модулів переробляються в єдиному циклі.

3 економічної точки зору залишається актуальним питання щодо рентабельності переробки сонячних модулів. Численні дослідження показують, що вартість брухту фотоелектричної електростанції (в основному сталь і мідь) перевищує витрати на виведення 3 експлуатації, тому переробка відходів вигідніше ïх поховання. Існує прямо пропорційна залежність: чим більші обсяги відходів (мінімум 20000 тон на рік), тим вище і прибутковіше процес переробки [10]. До того ж міжнародне законодавство жорстко контролює цей процес. Постійне зниження вартості сонячного обладнання відкриває можливості для збільшення потоку інвестицій в сферу утилізації фотоелектричних модулів.

В Україні на даний час підприємства по переробці фотоелектричних модулів відсутні, як і відсутні спеціальні вимоги щодо утилізації ФЕМ. В деякій мірі вимоги до утилізації фотоелектричних модулів окреслено в національних стандартах України ДСТУ 8328:2015 та ДСТУ 8635:2016 [11, 12], але цього недостатньо для якісного та повноцінного функціонування сфери утилізації ФЕМ.

Так як на сьогоднішній день кількість електронного сміття від сонячних модулів ще $\epsilon$ невелика, то утилізацію проводять підприємства, які займаються переробкою електронних або скляних відходів. У процесі такої переробки відбувається виділення основних компонентів модуля - міді, алюмінію, скла. Сонячні елементи та пластикові складові модулів, в свою чергу, піддаються спалюванню або відправляються на спеціальні полігони (звалища для електронного обладнання), тобто здійснюється груба переробка модулів, яка, за своєю суттю, $є$ технологією тільки вторинного застосування скла 3 ламінованим покриттям, що $є$ недостатнім і далеким від повноцінної утилізації ФЕМ та від досягнення екологічної чистоти утилізації.

Висновки. В Україні назріла необхідність розробки чітких нормативних вимог до утилізації відпрацьованих фотоелектричних модулів та створення функціональної структури зі збору та переробки фотоелектричних модулів із застосуванням новітніх технологій i методологічних підходів поводження із подібними відходами, спираючись на вже досягнутий європейський та світовий досвід, у відповідності до чинного законодавства України. Виконання цих задач має забезпечити:

- екологічну безпеку в Україні;

- запобігання шкідливим викидам за рахунок утилізації відпрацьованих ФЕМ 3 дотриманням необхідних жорстких вимог;

- створення нових робочих місць на підприємствах, що будуть займатися роботами 3 утилізації відпрацьованих ФЕМ;

- економію матеріальних і енергетичних ресурсів за рахунок повернення до подальшого повторного використання більшості матеріалів i 
сполук, отриманих за результатами утилізації відпрацьованих ФЕМ;

- створення передумов для активізації залучення недержавних інвестицій в розвиток цього напрямку утилізації.

1. Рєзиов В.Ф. Збірник рефератів дисертацій, НДР та ДКР № 0216U005119. Розробка комплексних заходів i методичних рекомендацій зі зменшення впливу на довкілля при будівництві та експлуатації фотоелектричних станцій: Заключний звіт. Інститут відновлюваної енергетики НАН України. ДР 0113U005151. 150 с.

2. Рєзиов В.Ф., Суржик Т.В., Пундєв В.О., Шевчук В.I., Кирнос Л.А., Шейко І.О. Вимоги щодо забезпечення екологічних факторів при впровадженні технологій фотоенергетики в Україні. Відновлювана енергетика. 2019. № 4(59). С.29-36.

3. Сонячна енергетика України. [Електронний pecypc]. URL: https://uk.wikipedia.org/wiki/Сонячна енергети ка України. (дата звернення: 14.07.20).

4. Weckend S., Wade A., Heath G. IRENA. IEA-PVPS End-of-life management: Solar Photovoltaic Panels [Електронний ресурc]. URL: https://www.irena.org/publication s/2016/Jun/End-of-life-management-Solar-Photovoltaic-Panels. (дата звернення: 14.07.20).

5. EN 50625-2-4. Collection, logistics \& treatment requirements for WEEE-Part 2-4: Treatment requirements for photovoltaic panels. 2017. $19 \mathrm{p}$.

6. CENELEC - CLC/TS 50625-3-5. Collection, logistics \& Treatment requirements for WEEE-Part 3-5: Technical specification for de-pollution-Photovoltaic panels. 2017. 16 p.

7. NSF/ANSI 457. Sustainability Leadership of Photovoltaic Modules. 2017. p. 45

8. Японія бере під повний контроль утилізацію сонячних батарей. УКРІНФОРМ. [Електронний ресурс]. URL: https://www.ukrinform.ua/rubric-technology/2647960aponia-bere-pid-povnij-kontrol-utilizaciu-sonacnih-batarej.html. (дата звернення: 14.07.20).

9. Holm N., Martin J. Solar Panel Recycling. Illinois Sustainable Technology Center. [Електронний pecypc]. URL: https://swanaillinois.org/images/files/users/swana10/N.Holm\&J. Martin ISTC Solar Power Facts.pdf . (дата звернення: 14.07.20)

10. Чи $\epsilon$ друге життя у сонячних панелей? [Електронний ресурc]. URL: https://avenston.com/ru/articles/so lar-second-life/.(дата звернення: 14.07.20).

11. ДСТУ 8328:2015. Геліоенергетика. Модулі фотоелектричні. Загальні технічні вимоги. Київ. ДП «УкрНДНЦ». 2016. 30 с.

12. ДСТУ 8635:2016. Геліоенергетика. Площадки для фотоелектричних станцій. Приєднання до електроенергетичної системи. Київ. ДП «УкрНДНЦ». 2016. 52 с.

\section{REFERENCES}

1. Reztsov V.F. Zbirnyk referativ dysertatsiy, NDR ta DKR № 0216U005119. Rozrobka kompleksnykh zakhodiv i metodychnykh rekomendatsiy zi zmenshennya vplyvu na dovkillya pry budivnytstvi ta ekspluatatsiyi fotoelektrychnykh stantsiy. [Collection of abstracts of dissertations, research and research № 0216U005119. Development of comprehensive measures and guidelines for reducing environmental impact in the construction and operation of photovoltaic plants]. Final Report. Renewable Energy Institute of the National Academy of Sciences of Ukraine. State Registration 0113U005151. 150 p. [in Ukranian].

2. Reztsov V.F., Surjyk T.V., Pundev V.O., Shevchuk V.I., Kirnos L.A., Sheyko I.O. Vymogy shchodo zabezpechennya ecologichnykh factoriv pry vprovadzhenni technology fotoenrgetyky $\mathrm{v}$ Ukrayini. [Requirements for providing environmental factors in implementation of photo energy technologies in ukraine]. Vidnovluvana energetika. 2019. No. 4(59). Pp. 29-36 [in Ukranian].

3. Sonyachna enerhetyka Ukrayiny. [Solar energy of Ukraine]. [Electronic resource]. URL: https://uk.wikipedia.org/w iki/Сонячна енергетика України. (Applying date: 14.07.20). [in Ukranian].

4. Weckend S., Wade A., Heath G. IRENA. IEA-PVPS: End-of-life management:Solar Photovoltaic Panels. [Electronic resource]. URL: https://www.irena.org/publications/2016/Jun/En d-of-life-management-Solar-Photovoltaic-Panels. (Applying date: 14.07.20). [in English].

5. EN 50625-2-4. Collection, logistics \& treatment requirements for WEEE-Part 2-4: Treatment requirements for photovoltaic panels. 2017. 19 p. [in English].

6. CENELEC - CLC/TS 50625-3-5. Collection, logistics \& Treatment requirements for WEEE-Part 3-5: Technical specification for de-pollution-Photovoltaic panels. 2017. 16 p. [in English]

7. NSF/ANSI 457. Sustainability Leadership of Photovoltaic Modules. 2017. 45 p. [in English].

8. Yaponiya bere pid povnyy kontrol utylizatsiyu sonyachnykh batarey. [Japan is taking full control of the disposal of solar panels]. UKRINFORM. [Electronic resource]. URL: https://www.ukrinform.ua/rubric-technology/2647960-aponiabere-pid-povnij-kontrol-utilizaciu-sonacnih-batarej.html. (Applying date: 14.07.20).

9. Holm N., Martin J. Solar Panel Recycling. Illinois Sustainable Technology Center. [Electronic resource]. URL: https://swanaillinois.org/images/files/users/swana10/N.Holm\&J. Martin ISTC Solar Power Facts.pdf . (Applying date: 14.07.20).

10. Chy ye druhe zhyttya u sonyachnykh paneley?. [Does solar panels have a second life?]. [Electronic resource]. URL: https://avenston.com/ru/articles/solar-second-life/. (Applying date: 14.07.20).

11. DSTU 8328:2015. Helioenerhetyka. Moduli fotoelektrychni. Zahalni tekhnichni vymohy. [DSTU 8328:2015. Solar energy. Photovoltaic modules. General technical requirements]. Kiev. DP "UkrNDNC". 2016. 30 p.

12. DSTU 8635:2016. Helioenerhetyka. Ploshchadky dlya fotoelektrychnykh stantsiy. Pryyednannya do elektroenerhetychnoyi systemy. [DSTU 8635: 2016. Solar energy. Sites for photovoltaic stations. Connection to the power system]. Kiev. DP "UkrNDNC". 2016. 52 p. 